DOI: $\square$ https://doi.org/10.15407/techned2020.06.005

\title{
MATHEMATICAL MODEL OF WAVE PROCESSES IN TWO-WINDING TRANSFORMERS
}

Journal

Publisher

ISSN

Issue

Pages
Tekhnichna elektrodynamika

Institute of Electrodynamics National Academy of Science of Ukraine 1607-7970 (print), 2218-1903 (online)

No 6, 2020 (November/December)

$5-14$

\section{Authors}

M.S. Seheda ${ }^{\star}$, Ye.V. Cheremnykh ${ }^{\star \star}$, P.F. Gogolyuk ${ }^{\star \star \star}$, T.A. Mazur ${ }^{\star \star \star \star}$, Y.V. Blyznak ${ }^{\star \star \star \star \star}$ Lviv Polytechnic National University,

12, S. Bandera Str., Lviv, 79013, Ukraine,

e-mail:mseheda@ukr.net, petro.f.hoholiuk@Ipnu.ua, mazyr@ukr.net,

blyznakyura@gmail.com

* ORCID ID : https://orcid.org/0000-0001-8459-5758

** ORCID ID : https://orcid.org/0000-0002-4621-2426

*** ORCID ID : https://orcid.org/0000-0003-0002-4638

**** ORCID ID : https://orcid.org/0000-0001-5021-4013

***** ORCID ID : https://orcid.org/0000-0002-4914-2283

\section{Abstract}

A mathematical model has been developed to study the wave processes of two-winding transformers, taking into account the electromagnetic connections between the turns of the winding and between the windings. To solve differential-integral equations in partial derivatives, a method of separation of variables is proposed. References 12, figures 2 .

Key words: transformer winding, mathematical modeling, partial derivatives, distributed parameters, impulse wave, wave processes. 
Accepted: 29.07 .2020

Published: 21.10.2020

\section{References}

1. Kyrylenko O.V., Seheda M.S., Butkevych O.F., Mazur T.A. Mathematical Modeling in Electric Power Engineering. Lviv: Lviv Polytechnic National University, 2013. 608 p. (Ukr)

2. Isaev Y.N., Startseva E.V., Schekotuev A.V. Investigation of wave processes of transformer windings as electric circuit with distributed parameters. Izvestiya Tomskogo Politekhnicheskogo universiteta. Inzhiniering energoresursov

. 2015. Vol. 326. No 8. Pp. 29-35. (Rus)

3. Lavrinovich V.A., Isaev Y.N., Mytnikov A.V. Advanced control state technology of transformer. International Journal on Technical and Physical Problems of Engineering. 2013. Vol. 5. Iss. 17. No 4. Pp. 94-98.

4. Mikulovic J. C., Sekara T. B. The Numerical Method of Inverse Laplace Transform for Calculation of Overvoltages in Power Transformers and Test Results. Serbian Journal of Electrical Engineering

2014. Vol. 11. No 2. Pp. 243-256.

DOI:

https://doi.org/10.2298/SJEE131123020M

5. Bontidean S. G., Badic M., Iordache M., Galan N. Simulations and experimental tests on the distribution of overvoltage within transformer windings. U.P.B. Sci. Bull. Series C. 2015. Vol. 77. Iss. 3.

6. de Azevedo A.C., Rezende I., Delaiba A.C., Oliveira C., de Carvalho B.C., de Bronzeado H.S. Investigation of transformer electromagnetic forces caused by external faults using FEM. I EEE PES Transmission and Distribution Conference and Exposition

. Venezuela, Latin America, 2006. Pp. 1-6.

DOI:

https://doi.org/10.1109/TDCLA.2006.311522

7. Seheda M.S., Cheremnykh Y.V., Mazur T.A. Mathematical modeling of free voltage oscillations on transformer windings into accout winds mutual induction under surge overvoltages. Scientific Bulletin of National Mining University. 2013. No 1 (133). Pp. 68-76. (Ukr)

8. Seheda M.S., Cheremnykh Y.V., Chimjk I.V., Mazur T.A., Kurylyshyn O.M. Mathematical modelling of stress distribution along the winding transformers under impulse surges. Tekhnichn a Elektrodynamika

. 2015. No 6. Pp. 8-11. (Ukr)

9. Hoholyuk O., Byczkowska-Lipinska L. Mathematical models of transformers for electromagnetic transient process simulation. Przeglad Electrotechniczny. 2008. No 6. Pp. 278-280.

10. Seheda M.S., Mazur T.A, Kurylyshyn O.M. Mathematical model for investigation of wave 
processes in high-voltage double winding transformers. 16th International Conference on Computational Problems of Electrical Engineering

(CPEE). Lviv, Ukraine, September 2-5, 2015. Pp. 165-167.

DOI:

https://doi.org/10.1109/CPEE.2015.7333366

11. Electrical Transient Interaction between Transformers and the Power System. Cigre. April, 2014.

12. Bewley L.B. Traveling waves on transmission systems. Moskwa-Leningrad: ONTI, 1938. $288 \mathrm{p}$.

$\underline{\text { PDF }}$

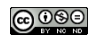

This work is licensed under a Creative Commons Attribution-NonCommercial-NoDerivatives 4.0 International License 